\title{
Verifying Capital Asset Pricing Model in Greek Capital Market
}

\author{
Mansoor Maitah $^{1}$, Khurshid Khudoykulov $^{2}$, Kholnazar Amonov $^{3} \&$ Umar Burkhanov $^{4}$ \\ ${ }^{1}$ Mansoor Maitah, Czech University of Life Sciences Prague, Prague 6, Czech Republic \\ ${ }^{2}$ Khurshid Khudoykulov, Educational Institution of Thessaloniki, Greece \\ ${ }^{3}$ Kholnazar Amonov, Central Bohemia University, o.p.s., Czech Republic \\ ${ }^{4}$ Umar Burkhanov, Tashkent State Universiy of Economics, Uzbekistan \\ Correspondence: Mansoor Maitah, Department of Economics, Faculty of Economics and Management, Czech \\ University of Life Sciences Prague, Kamycka 129, Prague 616921, Czech Republic. E-mail: maitah@pef.czu.cz
}

Received: January 23, 2015 Accepted: April 21, 2015 Online Published: June 13, 2015

doi:10.5539/ass.v11n16p55 URL: http://dx.doi.org/10.5539/ass.v11n16p55

\begin{abstract}
This article deals with capital asset valuation on Greek capital market using Capital Asset Pricing Model (CAPM). We examined 32 companies listed on the Athens Stock Exchange on a weekly basis for a period from June 2009 to December 2013 under this model. The CAPM model is tested by performing two-pass characteristic regression analyses. The first-pass characteristic line regression was used to estimate stocks of beta. Hence, the second-pass characteristic line regression was taken to analyze the intercept and the slope coefficients of stocks. The two characteristics of line regression verify the adequacy of the CAPM. According to our results, we came to a conclusion that there was a linear relationship between systematic risk and returns. The CAPM would be the verification of our major hypotheses from the time series tests. In order for this to be true, the intercept ought to be approximately equal to zero, supporting the theories for both individual assets and portfolios. However, the testing provides evidence against the CAPM, but do they do? It should be kept in mind that it does not necessarily represent evidence in favor of any alternative model.
\end{abstract}

Keywords: CAPM, coefficient Beta, securities market portfolio, systematic risk, market risk premium

\section{Introduction}

The CAPM (capital asset pricing model) is useful as a decision-support tool for corporate finance. Firms need to estimate their cost of capital to evaluate new investment projects that are considered capital budgeting decisions. For this reason, financial managers can use the CAPM to calculate the cost of their equity.

The CAPM is established on the basis of the modern theory of Markowitz portfolios. This type of CAPM was developed using a theory of modern portfolios by William F. Sharp (1963 and 1964) and John Linter. William F. Sharp was awarded the Nobel Prize. This CAPM is based on the assumption of positive risk-return trade-offs. The theory affirms that the expected return on every asset is a positive function of only one variable: its market beta (defined as the covariance of asset return and market return). The CAPM, being a theoretical model, is based on some key assumptions:

- All investors look at only one-period expectations about the future;

- Investors are price takers, and they cannot influence the market individually;

- There is a risk-free rate for which any investor lends or borrows money;

- Investors are risk-averse;

- Taxes and transaction costs are irrelevant.

One of the major results of the CAPM is the proof of the relationship between expected risk premiums on special assets and their "systematic risk." This relationship shows that the expected return on every asset is directly proportional to its "systematic risk." This study aims to test the standard form of the CAPM in the Greek capital market. The study was divided into four parts. The first part represents the introduction, and the next part reviews some of the empirical evidences on the CAPM. The third part considers the CAPM for methodology application and data selection. The last contains a verification of the CAPM and analysis of the results. Finally, a summary and some conclusions will be given. 


\section{Literature Review}

The CAPM built on the model of choice was developed by Markowitz (1959) and Tobin (1958). They developed the "risk-return portfolio theory" based on the benefits model of von Neumann and Morgenstern (1953). The model assumes that investors are risk-averse when choosing among portfolios. Markowitz selected the "mean-variance-efficient" stock portfolios to be used in his model. After that, the CAPM model was developed independently by Sharpe (1964), Linter (1965), and Mossin (1966). They added two fundamental hypotheses to the Markowitz model to determine one portfolio that must be mean-variance-efficient. The development of the Sharpe-Lintner version of the CAPM is to use the assumption of risk-free borrowing and lending the expected return on zero-beta assets. The expected return on any asset that is uncorrelated with the market return must equal the risk-free rate. Thus, the Sharpe-Lintner CAPM becomes the familiar relationship between expected return and beta.

Starting in the later 1970s, Fisher Black developed a version of the CAPM without risk-free borrowing and lending. The unlimited risk-free borrowing and lending was said to be an unrealistic assumption by Fisher Black. Later, Jensen Scholes (1972) studied and extended the notions, and Fama and Macbeth (1973) highlighted the proof of a larger intercept than the risk-free interest rate. After that, the CAPM based on Basu's empirical studies (1977) found some evidence for common stocks classified on earnings-price ratios. He showed that the future returns on high E/P stocks are higher than those foretold by the CAPM. Banz (1981) includes a size effect, that is, stocks classified in exchange market capitalization average returns on small stocks are higher than foretold by the CAPM. Bhandari (1988) found evidence that high debt-equity ratios are related to returns that are overwhelmingly high on their market betas. Finally, researchers Statman (1980) and Rosenberg, Reid, and Lanstein (1985) proved that the stocks with high book-to-market equity ratios have high average returns that are not captured by their betas. Later, Fama and French (1992) confirmed the evidence given by researchers such as Reinganum (1981), Stambaugh (1982), and Lakonishok and Shapiro (1986). He was able to show that the relationship between return and beta for common stocks is even lower after the sample period is used in the early empirical work on the CAPM. The estimate of the beta premium, however, is clouded by the statistical ineffectiveness (a large standard error). Kothari, Shanken, and Sloan (1995) tried to resuscitate the Sharpe-Lintner CAPM by showing that the weak relation between return and beta is just a chance result. However, the strongest proof, the other variables that obtain variation in expected return missed by beta, makes this argument irrelevant.

Other researchers have examined the correlation between expected return and the beta coefficient. Michailidis, Tsopoglou, Papanastasiou, and Mariola (2006) tested the CAPM on the stock market in Greece. They showed that in contrast to the basic hypothetical models, a high expected return does not expect a high level of risk. Choudhary and Choudary (2010) also came to this conclusion by examining the stock market in India. There is also an example that confirms the main settings of the model, in particular, by research carried out on the stock market in Italy (Canegrati, 2008). Trifan A. L. (2009), who conducted research in the stock market in Romania in 2009 , showed that the regression model has no statistical significance, and the results of this examination do not give specific evidence against the CAPM.

\section{Method}

In this part, we examined the CAPM practicing regression equation method in the ASE. The capital asset pricing model (CAPM) could be written as follows:

$$
E(R i)=R f+\beta i(R m-R f)
$$

Where:

$\mathrm{E}(\mathrm{Ri})=$ the expected return on assets $\mathrm{i}$;

$\mathrm{Rf}=$ the risk-free rate calculated as the average of the interest rates on government treasury bills:

$\mathrm{Rf}=7.04 \%$ The Government treasury bill yields were taken from Central Bank of Greece website. http://www.bankofgreece.gr/

$\beta i=\operatorname{Cov}(\mathrm{Ri} R \mathrm{R}) / \sigma^{2}\left(\mathrm{R}_{\mathrm{m}}\right)$ the volatility (risk) of the asset "i" related to the market portfolio $\mathrm{M}$;

$\mathrm{Rm}=$ the expected return on the market portfolio $\mathrm{M}$;

$\mathrm{Rm}$ Calculate the Arithmetic mean the Athen Index Compos average return during the period from 1988 to 2013.

$\mathrm{Rm}=9.8487 \%$

$\mathrm{Rm}-\mathrm{Rf}=$ the excess return over the risk-free rate return. The risk premium for bearing one unit of beta risk; 
Starting at the closing prices has resulted from weekly returns:

$\mathrm{Rt}=\ln (\mathrm{Pt} / \mathrm{Pt}-1)$ using the approximation $\ln (1+\mathrm{x}) \approx \mathrm{x}$. when $\mathrm{x} \rightarrow 0$

The beta coefficient is an index of unverifiable (systematic) risk. Betas for different stocks may be ranked to compare the systematic risk of the stocks. We can see the interpretation of coefficient Beta $(\beta)$ in Table 1 below.

Table 1. Interpretation of coefficient Beta $(\beta)$

\begin{tabular}{|c|c|c|}
\hline Beta & $\begin{array}{l}\text { Direction of changes in } \\
\text { security's return in } \\
\text { comparison to the } \\
\text { changes in market return }\end{array}$ & Interpretation of $\beta$ meaning \\
\hline$\beta_{\mathrm{i}}>1$ & The same as market & Volatility (risk) of stock is higher than market risk \\
\hline$\beta_{\mathrm{i}}=1$ & The same as market & Stock's volatility (risk) is equal to market risk \\
\hline$\beta_{\mathrm{i}}<1$ & The same as market & Stock's volatility (risk) lower than market risk \\
\hline$\beta_{\mathrm{i}}=0$ & There is no relationship & Stock's risk is not influenced by market risk \\
\hline$\beta_{\mathrm{i}}<0$ & $\begin{array}{l}\text { The opposite from the } \\
\text { market }\end{array}$ & Stock's volatility (risk) lower than market risk but in the opposite direction \\
\hline
\end{tabular}

Source: own processing

\subsection{Data Selection}

The study applies to the CAPM on the Athens Stock Exchange (ASE) data with the aim of interpreting and considering the utility of the standard estimates. The research on the CAPM standard carried in it the common stocks of 32 companies belonging to flourishing industries in the Greek economy, including telecom, software, construction, infrastructure, finance, and banking, listed on the Athens Stock Exchange (ASE). A series of weekly data were used for the econometric analysis. For this reason, the collected data were weekly closing prices of common stocks traded on the Athens Stock Exchange. This data was taken from www.investing.com, a financial website. The study period was from June 01, 2009 to December 31, 2013. In addition, the database of the Athens Stock Exchange (ASE) served as a data source on the closing prices for each company; that is, its weekly market reports helped to evaluate those companies. The number of observations for each company was 238. ASE Composite (General) was used as a proxy for the market portfolio. The market return was taken from the Share Price Index of the ASE Composite (General). This data, in turn, was taken from the investing.com website. The empirical testing of the CAPM model was carried out using the software package EViews and the MS Excel spreadsheet program.

\subsection{The Empirical Test of the CAPM Model}

Table 2. CAPM-estimated coefficients and statistics for time series. The entire period (June 2009-December 2013)

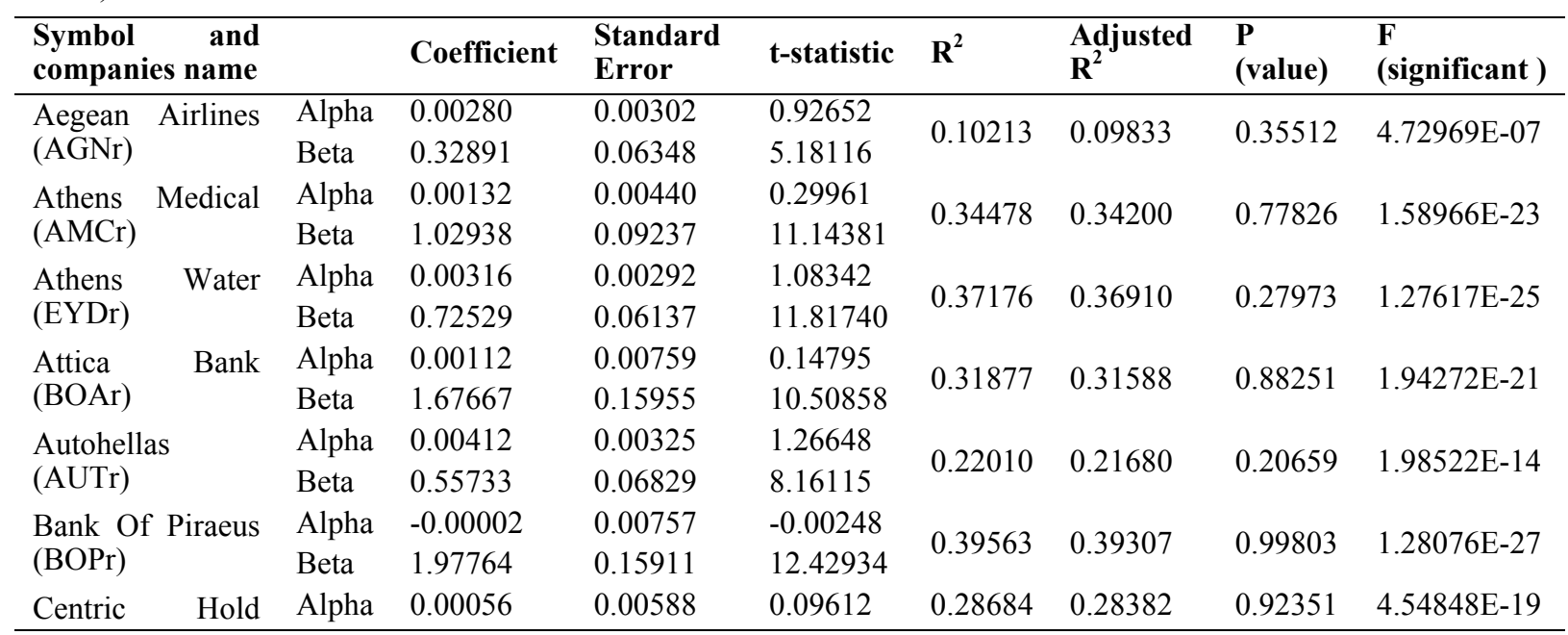




\begin{tabular}{|c|c|c|c|c|c|c|c|c|}
\hline $\begin{array}{l}\text { Symbol and } \\
\text { companies name }\end{array}$ & & Coefficient & $\begin{array}{l}\text { Standard } \\
\text { Error }\end{array}$ & t-statistic & $\mathbf{R}^{2}$ & $\begin{array}{l}\text { Adjusted } \\
\mathbf{R}^{2}\end{array}$ & $\begin{array}{l}\text { P } \\
\text { (value) }\end{array}$ & $\begin{array}{l}\text { F } \\
\text { (significant) }\end{array}$ \\
\hline (DESr) & Beta & 1.20304 & 0.12348 & 9.74276 & & & & \\
\hline \multirow{2}{*}{$\begin{array}{l}\text { Corinth } \quad \text { Pipe } \\
(\mathrm{COR})\end{array}$} & Alpha & 0.00497 & 0.00384 & 1.29311 & \multirow{2}{*}{0.45171} & \multirow{2}{*}{0.44939} & \multirow{2}{*}{0.19724} & \multirow{2}{*}{$1.22578 \mathrm{E}-32$} \\
\hline & Beta & 1.12592 & 0.08075 & 13.94385 & & & & \\
\hline \multirow{2}{*}{ Elval (VAL) } & Alpha & 0.00498 & 0.00385 & 1.29340 & \multirow{2}{*}{0.34660} & \multirow{2}{*}{0.34383} & \multirow{2}{*}{0.19714} & \multirow{2}{*}{$1.35907 \mathrm{E}-23$} \\
\hline & Beta & 0.90575 & 0.08095 & 11.18861 & & & & \\
\hline \multirow{2}{*}{$\begin{array}{l}\text { Euro } \\
\text { (EREr) }\end{array}$} & Alpha & 0.00490 & 0.00380 & 1.29177 & \multirow{2}{*}{0.20009} & \multirow{2}{*}{0.19670} & \multirow{2}{*}{0.19770} & \multirow{2}{*}{ 4.13093E-13 } \\
\hline & Beta & 0.61305 & 0.07979 & 7.68338 & & & & \\
\hline \multirow{2}{*}{$\begin{array}{l}\text { Folli } \\
\text { (HDFr) }\end{array}$} & Alpha & 0.00536 & 0.00390 & 1.37665 & \multirow{2}{*}{0.24361} & \multirow{2}{*}{0.24041} & 016992 & $510398 \mathrm{E}-16$ \\
\hline & Beta & 0.71371 & 0.08186 & 8.71837 & & & 0.10992 & $5.10590 \mathrm{D}-10$ \\
\hline Fourlis & Alpha & 0.00256 & 0.00491 & 0.52027 & 033667 & 033386 & 060337 & $816281 F_{-23}$ \\
\hline (FRLr) & Beta & 1.12968 & 0.10322 & 10.94448 & $500 /$ & & & $0.10201 \mathrm{~L}-25$ \\
\hline Friogolass (FRIr) & Alpha & 0.00319 & 0.00341 & 0.93405 & 030800 & 030506 & 035123 & $125742 \mathrm{E}-20$ \\
\hline 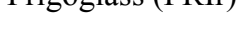 & Beta & 0.73547 & 0.07176 & 10.24885 & 0.50000 & 0.50000 & 0.53125 & $1.25 / 42 \mathrm{E}-20$ \\
\hline Terna & Alpha & 0.00358 & 0.00407 & 0.88106 & 048361 & 048142 & 037018 & $100506 F_{-} 35$ \\
\hline (HRMr) & Beta & 1.27077 & 0.08548 & 14.86660 & 0.48501 & 0.48142 & 0.37918 & $1.00590 E-35$ \\
\hline Grivalia & Alpha & 0.00239 & 0.00296 & 0.80774 & 012706 & 012336 & 0.42005 & $154025 \mathrm{~F}_{-} 08$ \\
\hline Properties REIC & Beta & 0.36501 & 0.06228 & 5.86088 & $0.12 / 00$ & 0.12350 & 0.42005 & $1.540 \angle 5 E-08$ \\
\hline Halcor (XAKO) & Alpha & 0.00254 & 0.00417 & 0.60929 & & & & \\
\hline Haicor ( $\mathrm{AAKU}$ ) & Beta & 1.15150 & 0.08754 & 13.15448 & 0.42304 & 0.42060 & 0.54292 & $5.18312 \mathrm{E}-30$ \\
\hline Hell.Exchanges & Alpha & 0.00404 & 0.00287 & 1.40991 & 055957 & 055770 & 015988 & $656816 \mathrm{~F}_{-} 44$ \\
\hline$(\mathrm{EXCr})$ & Beta & 1.04343 & 0.06026 & 17.31580 & 1 & $0.531 / 0$ & 0.13900 & $0.500100-44$ \\
\hline Hellenic & Alpha & 0.00406 & 0.00350 & 1.16110 & 048290 & 0.48071 & 024678 & $118239 F_{-} 35$ \\
\hline (OTEr) & Beta & 1.09150 & 0.07352 & 14.84564 & 0.40230 & $0.400 / 1$ & 0.24010 & 1.102Jע- \\
\hline Hyoia (HYGr) & Alpha & -0.00130 & 0.00453 & -0.28766 & 037110 & 006088 & 077386 & $860116 \mathrm{~F}-26$ \\
\hline Hygerd (H Y Ur) & Beta & 1.13081 & 0.09527 & 11.87015 & $0.3 / 119$ & 0.00900 & $0.1 / 300$ & $0.00110 \mathrm{E}-20$ \\
\hline Intracom & Alpha & 0.00108 & 0.00430 & 0.25186 & 0.47708 & 0.47486 & 0.80137 & $4.45968 \mathrm{E}-35$ \\
\hline & Beta & 1.32669 & 0.09041 & 14.67345 & & & & \\
\hline Intralot (INU $r)$ & Alpha & 0.00004 & 0.00388 & 0.01085 & 030548 & 030254 & 000135 & $103726 \mathrm{~F}_{-20}$ \\
\hline intralot (INLr) & Beta & 0.83168 & 0.08163 & 10.18841 & 0.50548 & 0.50254 & 0.99155 & $1.93 / 20 E-20$ \\
\hline J. \& P. Avax & Alpha & 0.00202 & 0.00343 & 0.58826 & 0.45132 & 044900 & 055692 & $133372 \mathrm{~F}-32$ \\
\hline (AVAr) & Beta & 1.00354 & 0.07203 & 13.93287 & & & 0.53092 & $1.535 / 2 \mathrm{~L}-52$ \\
\hline Kleeman & Alpha & 0.00310 & 0.00379 & 0.81791 & 018577 & 018232 & 041423 & $347436 \mathrm{~F}_{-12}$ \\
\hline (KLEr) & Beta & 0.58417 & 0.07961 & 7.33793 & $0.10 \mathrm{~J} / 1$ & 0.10252 & 0.41425 & $3.4 / 450 \mathrm{~L}-12$ \\
\hline Lamda Develop & Alpha & 0.00262 & 0.00400 & 0.65569 & 015429 & 015070 & 051266 & $333897 \mathrm{E}-10$ \\
\hline (LMDr) & Beta & 0.55152 & 0.08405 & 6.56162 & & & & \\
\hline Marfin & Alpha & -0.00041 & 0.00523 & -0.07843 & 047372 & 047140 & 0.03755 & 0 5250F 35 \\
\hline (MRFr) & Beta & 1.60229 & 0.10993 & 14.57498 & $0.4 / 3 / 2$ & $0.4 / 149$ & 0.95153 & $9.52395-53$ \\
\hline Metka (MTKr) & Alpha & 0.00391 & 0.00267 & 1.46560 & 043008 & 042766 & 014409 & $12082 \mathrm{E}-30$ \\
\hline & Beta & 0.74901 & 0.05613 & 13.34509 & 0.45008 & & & \\
\hline Mytilineos & Alpha & 0.00456 & 0.00260 & 1.75623 & 068615 & & 008035 & \\
\hline (MYTr) & Beta & 1.23998 & 0.05459 & 22.71468 & 0.00015 & 0.08482 & 0.00053 & $2.50350 \mathrm{E}-01$ \\
\hline Natl. Bank & Alpha & -0.00212 & 0.00589 & -0.35932 & 046983 & 046758 & 071968 & $228204 \mathrm{E}-34$ \\
\hline (NBGr) & Beta & 1.79150 & 0.12388 & 14.46159 & & & & \\
\hline Nireus & Alpha & -0.00030 & 0.00385 & -0.07701 & 038463 & 038203 & 003868 & $100118 \mathrm{~F}$ \\
\hline$(\mathrm{NIRr})$ & Beta & 0.98394 & 0.08101 & 12.14528 & 0.58403 & 0.38202 & 0.93808 & $1.09118 \mathrm{E}-20$ \\
\hline Public & Alpha & 0.00408 & 0.00404 & 1.01019 & 043830 & 043592 & 031344 & $215603 \mathrm{~F}-31$ \\
\hline (DEHr) & Beta & 1.15256 & 0.08493 & 13.57021 & & & 0.31344 & \\
\hline Sidenor (SID) & Alpha & 0.00059 & 0.00408 & 0.14367 & 046010 & 045700 & 088588 & $103205 \mathrm{~F}_{3} 32$ \\
\hline sidenor (SID) & Beta & 1.21673 & 0.08578 & 14.18413 & 0.40019 & $0.45 / 90$ & 0.88588 & $1.93203 E-33$ \\
\hline Techn Olympic & Alpha & 0.00059 & 0.00408 & 0.14367 & 046019 & 045790 & 061055 & $352031 \mathrm{E}-10$ \\
\hline (OLYr) & Beta & 1.21673 & 0.08578 & 14.18413 & 0.40019 & 0.45190 & 0.01053 & $3.520312-10$ \\
\hline
\end{tabular}

Source: own processing 
The following is the estimate of the CAPM regression equation. The values for alpha and beta coefficients and other statistics measures are presented in the table below.

\subsection{The Results of the Empirical Test on the CAPM Model}

The results, which estimated beta coefficients from the table 2 above, range from 0.3289 to 1.9776 . We can notice that all the stocks of $\alpha$ intercepts are positive except those of five securities. This shows that the high-risk securities earned more on average over this time than the projections of this asset pricing model. As a result, these results illustrate the great deviation from the standard model of the CAPM.

Based on a confidence coefficient level of $95 \%$, we move on to our t-test. According to statistics, a confidence level of $95 \%$ gives a t-statistic value equal to1.96. A special case of the t-test occurs if we test the hypothesis in which a parameter equals zero: $\mathrm{Ho}: \mathrm{Bi}=0$. If this hypothesis is rejected, then we conclude that the regression has a significant value for explaining the regression; if the hypothesis is not rejected, the regression has no significant explanatory value. According to this rule, the t-statistics is less than 1.96. Given our hypothesis condition that the intercept is equal to zero, if the t-statistics is higher than 1.96, our hypothesis rule does not work here, and the CAPM model is rejected for the ASE.

The table above illustrates the numbers derived using the CAPM model; they are proven to be applicable to the portfolios, according to the t-statistic values. We can see all the portfolios that are lower than 1.96 based on our hypothesis rule, and the CAPM model is rejected in the ASE. Another key relationship between the t-statistic values and the P values in statistics gives us an insight into the CAPM model. In this case, in the confidence level of 5\%, when the $\mathrm{P}$ values are higher than 0.05 , then the intercept should be equal to zero. If they are higher than 0.05 , the CAPM model does not hold in the ASE, as the null hypothesis does not hold. The R-square, a practical measure that ranges from 0 to 1 , gives the percentage of the total variance of that market risk; the remaining percentage is non-market risk. In addition to this, the R-square that measures the proportion of variation in the dependent variable, the explanation of which is given by the help of the independent variable, is also calculated for the 32 stocks. However, the R-square values, as seen in this table, are also very low. In the CAPM context, R-square measures the market (systematic) share of the total risk. However, it should be noted that $1-\mathrm{R}^{2}$ is the proportion of total risk that is specific (unsystematic risk). It is obvious that the systematic part of the risk fails to explain the special stock's risk premium due to a small value of $\mathrm{R}$-square $\left(\mathrm{R}^{2}\right)$. Now, considering all the above-cited conditions, we can show the evaluations of coefficient of determination and standard error of the regression in Table 3.

Table 3. Evaluations of coefficient of determination and standard error of the regression

\begin{tabular}{lllllllll}
\hline Number & Symbol & $\boldsymbol{R}^{\mathbf{2}}$ & $\begin{array}{l}\text { Standard error } \\
\text { the regression }\end{array}$ & Number & Symbol & $\boldsymbol{R}^{2}$ & $\begin{array}{l}\text { Standard error of } \\
\text { the regression }\end{array}$ \\
\hline $\mathbf{1}$ & AMCR & 0.34478 & 0.06775 & $\mathbf{1 7}$ & XAKO & 0.42303 & 0.06421 \\
$\mathbf{2}$ & BOPR & 0.22010 & 0.05009 & $\mathbf{1 8}$ & FRIR & 0.30799 & 0.05263 \\
$\mathbf{3}$ & CORR & 0.28683 & 0.09057 & $\mathbf{1 9}$ & GRIR & 0.12705 & 0.04568 \\
$\mathbf{4}$ & DESR & 0.28683 & 0.09057 & $\mathbf{2 0}$ & HRMR & 0.48360 & 0.06270 \\
$\mathbf{5}$ & VAL & 0.34659 & 0.05938 & $\mathbf{2 1}$ & INRR & 0.47707 & 0.06632 \\
$\mathbf{6}$ & AGNR & 0.10213 & 0.04656 & $\mathbf{2 2}$ & NIRR & 0.38462 & 0.05942 \\
$\mathbf{7}$ & AUTR & 0.22010 & 0.05009 & $\mathbf{2 3}$ & DEHR & 0.38462 & 0.05942 \\
$\mathbf{8}$ & BOAR & 0.31876 & 0.11703 & $\mathbf{2 4}$ & KLER & 0.45132 & 0.05283 \\
$\mathbf{9}$ & ERER & 0.20009 & 0.05852 & $\mathbf{2 5}$ & MTKR & 0.43007 & 0.04117 \\
$\mathbf{1 0}$ & EYDR & 0.37175 & 0.04502 & $\mathbf{2 6}$ & NBGR & 0.46982 & 0.09087 \\
$\mathbf{1 1}$ & FRLR & 0.33667 & 0.07571 & $\mathbf{2 7}$ & OLYR & 0.15391 & 0.07372 \\
$\mathbf{1 2}$ & HYGR & 0.37383 & 0.06988 & $\mathbf{2 8}$ & SID & 0.46018 & 0.06292 \\
$\mathbf{1 3}$ & EXCR & 0.55956 & 0.04420 & $\mathbf{2 9}$ & AVAR & 0.45132 & 0.05283 \\
$\mathbf{1 4}$ & HDFR & 0.24361 & 0.06004 & $\mathbf{3 0}$ & LMDR & 0.15428 & 0.06165 \\
$\mathbf{1 5}$ & INLR & 0.47707 & 0.06632 & $\mathbf{3 1}$ & MRFR & 0.47371 & 0.08064 \\
$\mathbf{1 6}$ & OTER & 0.48290 & 0.05393 & $\mathbf{3 2}$ & MYTR & 0.68615 & 0.04004 \\
\hline
\end{tabular}

Source: own processing 
The table represents that the relations between beta and expected return measured by the linear correlation coefficient are positive and rather weak in all companies. That means that all the companies' stocks have their variation in excess return fairly explained by the excess return on the market index. This equation applies in cases where there are fairly efficient betas explaining the correlation between market risk and return.

Table 3 shows the adjusted $\mathrm{R}^{2} \mathrm{~s}$, which are all positive and show a significant linearity in the model. Adjusted $\mathrm{R}^{2} \mathrm{~s}$ range from 0.68615 to 0.0698 for stocks between 1 and 32 , which means that the return volatility can be attributed to fluctuations in the market return by only $69 \%$ and $7 \%$, respectively. Apart from this, the adjusted $\mathrm{R}^{2}$ shows that the independent variable of the market premium can explain 0.68615 of variation in stock, which is the dependent variable of 0.55956 . The second variation for stock two is the variation of 0.48360 for stocks three and so forth. It continues in that manner because of the relationship between the returns on the securities and the return on the market. The standard deviation of the average weekly returns and the standard deviation of the residuals appear to be quite small in all the stocks. Subsequently, the t-test significance is the crucial value that helps us accept or reject the null hypothesis in the examination. That is the hypothesis about the significance of the model. It is important to hold on a significance level of 5\% if the F-test significance is lower than 0.05 . Therefore, we may conclude that there is a linear interdependence between the independent and the dependent variables. In this case, whether to accept or not is the matter of the rejection of the null hypothesis. That is, if the F-test is higher than 0.05 , then we accept that, but there is no interdependence between the variables. Table 2 illustrates that all portfolios at F-test significance values are higher than 0.05 , which means $(>5 \% \rightarrow \mathrm{Ho})$. For this reason, the initial hypothesis, in which the evaluated regression model is not statistically significant in all portfolios, is accepted. After all stocks had been tested, we concluded that the regression model CAPM is not only representative but also not statistically considerable in all stocks, which makes the possibility of applying the CAPM model in these markets very questionable. Hence, the coefficient of linear correlation measures the relationship between beta and expected returns. The results illustrate that a weak relationship has been established. The CAPM model's main prediction that an investor requires the compensation in the form of the risk premium only for the market risk and not for the unique risk is rejected here. However, the reason for the rejection of this assumption may be that we study stocks individually, not the portfolios in which the unique risk are eliminated in the individual stocks. However, the return of the unique risk is not eliminated, and this contributes towards the returns that investors demand on individual stocks.

\section{Conclusion}

To sum up, we can confirm that after testing the CAPM model, it is evident that the model was not adequate for evaluating the data in the Athens Stock Exchange market during the period between the $1^{\text {st }}$ of June 2009 and the $31^{\text {st }}$ of December 2013. The evidence discussed above does not completely lead us to a conclusion that the CAPM is absurd, since only stocks were included in the analyses. The market portfolio holds all the capital assets. According to the CAPM theory, the higher the asset risk (beta), the higher the expected rate of return will be for all assets that lie on the SML. The tests confirm the validity of beta as a measure of risk using regression analysis, and it was found that higher returns do not mean a higher beta linear on the SML. For this reason, it is not a valid measure of risk in these markets. Also, the conditions of the CAPM, in which the intercept is equal to zero and there is a higher positive expected return for bearing risk in the capital markets, are rejected. The large value of residual error also shows that the non-market factors (the unique factors) also contribute towards an asset's excess returns. The standard CAPM model is rejected owing to the fact that a number of factors are rough estimates; that is, incomplete information is available in the markets. Besides this, investing in the individual stocks rather than in the portfolios is another reason under consideration. We take results into account in the case where the CAPM model is not applied. Thus, the results show that the CAPM model is rejected in the Athens Stock Exchange. If the CAPM model were accepted in the Athens Stocks Market, managers could be able to analyze the cost of equity, which constitutes a major component in the cost of capital. In our view, the other alternative models are established in the Athens Stocks Exchange market, such as APT, GCAPM, ICAPM, and CCAPM.

\section{References}

Banz, R. W. (1981). The Relationship between Return and Market Value of Common Stocks. Journal of Financial Economics, 9(1), 3-18. http://dx.doi.org/10.1016/0304-405X(81)90018-0

Basu, S. (1977). Investment Performance of Common Stocks in Relation to Their Price-Earnings Ratios: A Test of the Efficient Market Hypothesis. Journal of Finance, 12(3), 129-156. http://dx.doi.org/10.1111/j.15406261.1977.tb01979.x 
Bhandari, L. C. (1988). Debt/Equity Ratio and Expected Common Stock Returns: Empirical Evidence. Journal of Finance, 43(2), 507-528. http://dx.doi.org/10.1111/j.1540-6261.1988.tb03952.x

Black, F. (1972). Capital Market Equilibrium with Restricted Borrowing. Journal of Business, 45(3), 444-454. http://dx.doi.org/10.1086/295472

Black, F., Jensen, M. C., \& Scholes, M. (1972). The Capital asset pricing model: Some empirical tests. In M. C. Jensen (Ed.), Studies in the Theory of Capital Markets (pp. 79-124). Praeger: New York.

Canegrati, E. (2008). Testing the CAPM: Evidences from Italian Equity Markets. MPRA Paper. Retrieved from http://mpra.ub.unimuenchen.de/10407/1/MPRA_paper_10407.pdf

Choudhary, K., \& Choudary, S. (2010). Testing Capital Asset Pricing Model: Empirical Evidences from India Equity Market. Eurasian Journal of Business and Economics, 3(6), 127-138.

Fama, E. F., \& Kenneth, R. F. (1992). The Cross-Section of Expected Stock Returns. Journal of Finance, 47(2), 427-465. http://dx.doi.org/10.1111/j.1540-6261.1992.tb04398.x

Fama, E. F., \& MacBeth, J. D. (1973). Risk, return and Equilibrium: Empirical Tests. The Journal of Political Economy, 81(3), 607-636. http://dx.doi.org/10.1086/260061

Kothari, S. P., Shanken, J., \& Richard, G. S. (1995). Another Look at the Cross-Section of Expected Stock Returns. Journal of Finance, 50(1), 185-224. http://dx.doi.org/10.1111/j.1540-6261.1995.tb05171.x

Lakonishok, J., \& Shapiro, A. C. (1986). Systematic Risk, Total Risk, and Size as Determinants of Stock Market Returns. Journal of Banking and Finance, 10(1), 115-132. http://dx.doi.org/10.1016/0378-4266(86)90023-3

Lintner, J. (1965). The Valuation of Risk Assets and the Selection of Risky Investments in Stock Portfolios and Capital Budgets. Review of Economics and Statistics, (47), 13-37. http://dx.doi.org/10.2307/1924119

Maitah, M., Saleem, N., Malec, K., Boubaker, M., \& Gouda, S. (2015). Economic Value Added and Stock Market Development in Egypt. Asian Social Science, 11(3).

Markowitz, H. (1959). Portfolio Selection: Efficient Diversification of Investments. New York: Wiley.

Michailidis, G., Tsopoglou, S., Papanastasiou, D., \& Mariola, E. (2006). Testing the Capital Asset Pricing Model (CAPM): The Case of the Emerging Greek Securities Market. International Research Journal of Finance and Economics, 4, 78-91.

Mossin, J. (1966). Equilibrium in a Capital Asset Market. Econometrica, 35, 768-783. http://dx.doi.org/10.2307/ 1910098

Reinganum, M. R. (1981). A New Empirical Perspective on the CAPM. Journal of Financial and Quantitative Analysis, 16(4), 439-462. http://dx.doi.org/10.2307/2330365

Rosenberg, B., Reid, K., \& Lanstei, R. (1985). Persuasive Evidence of Market Inefficiency. Journal of Portfolio Management, 11, 9-17. http://dx.doi.org/10.3905/jpm.1985.409007

Sharpe, W. F. (1964). Capital Asset Prices: A Theory of Market Equilibrium under Conditions of Risk. Journal of Finance, (19), 425-442.

Stambaugh, R. F. (1982). On The Exclusion of Assets from Tests of the Two-Parameter Model: A Sensitivity Analysis. Journal of Financial Economics, 10(3), 237-268. http://dx.doi.org/10.1016/0304-405X(82) 90002-2

Stattman, D. (1980). Book Values and Stock Returns. The Chicago MBA: A Journal of Selected Papers, 4, $25-45$.

Tobin, J. (1958). Liquidity Preference as Behavior toward Risk. Review of Economic Studies, 25(2), 65-86. http://dx.doi.org/10.2307/2296205

Trifan, A. (2009). Testing Capital Asset Pricing Model for Romanian Capital Market. Annales Universitatis Apulensis Series Oeconomica, 11(1), 426-434.

\section{Copyrights}

Copyright for this article is retained by the author(s), with first publication rights granted to the journal.

This is an open-access article distributed under the terms and conditions of the Creative Commons Attribution license (http://creativecommons.org/licenses/by/3.0/). 